\title{
Anti-inflammatory Activity of Matricaria recutita L. against Acute and Chronic Inflammatory Models
}

\author{
Katti HR ${ }^{1}$, Singh $\mathrm{P}^{2}$, Ramkishan $\mathrm{A}^{3}$, Chandrashekhar $\mathrm{VM}^{2 *}$, Sowmya $\mathrm{C}^{2}$ and Panji $M \mathrm{~A}^{2}$ \\ ${ }^{1}$ Department of Orthopedics, S. Nijalingappa Medical College and Research Centre, Bagalkot-587101, \\ Karnataka, India \\ ${ }^{2}$ Department of Pharmacology, Hanagal Shri Kumareshwar College of Pharmacy, BVVS Campus, \\ Bagalkot-587101, Karnataka, India
}

${ }^{3}$ Central Drugs Standard Control Organization, Subzonal office, Airport, Ahmedabad-380015, Gujarat

\begin{tabular}{|c|c|}
\hline \multirow{11}{*}{$\begin{array}{l}\text { Abstract } \\
\text { Chamomile (Matricaria recutita L.) is most popular used medicinal plant and extensively } \\
\text { consumed as a tea and food. We investigated the effects of Matricaria recutita L. (MR) in } \\
\text { acute and chronic inflammatory conditions. The anti-inflammatory activity of Matricaria } \\
\text { recutita was studied against carrageenan induced hind paw, arachidonic acid, acetic acid } \\
\text { and complete Freund's adjuvant (CFA)-induced arthritis in rats. The methanol extract of } \\
\text { Matricaria recutita was administered at the dose of } 100,200 \text { and } 300 \mathrm{mg} / \mathrm{kg} \text { body weight. } \\
\text { In CFA-induced model ESR, vascular permeability, histamine release from blood and } \\
\text { biochemical parameters were carried out. Chamomile methanol extract showed dose } \\
\text { dependent significant ( } P<0.001 \text { ) anti-inflammatory activity by inhibition of rat paw } \\
\text { oedema against carrageenan and arachidonic acid and inhibition of writhing induced by } \\
\text { acetic acid. The significant anti-arthritic activity was observed with administration of } \\
\text { Chamomile extract in the Freund's adjuvant induced model of arthritis. Chronic treatment } \\
\text { of extract of Chamomile showed significant decrease the development of arthritis and } \\
\text { reduced ESR observed. It also reduced the histamine release from blood and vascular } \\
\text { permeability at joint. The methanol extract of Matricaria recutita possess potential anti- } \\
\text { inflammatory activity against acute and chronic inflammatory model. }\end{array}$} & n \\
\hline & \\
\hline & : 26-03-2014 \\
\hline & Accepted : 28-03-2014 \\
\hline & \\
\hline & rthritis \\
\hline & lavonoid \\
\hline & d's adjuvant \\
\hline & \\
\hline & $v$ \\
\hline & \\
\hline
\end{tabular}

\section{INTRODUCTION}

Inflammation typically characterized by redness, swelling and pain. It is one of the most important host defense mechanisms against invading pathogens. Rheumatoid arthritis (RA) is a chronic inflammatory disease affecting the synovial joints that leads to joint destruction, which is responsible for the deformity and disability (Buch and Emery, 2002; Katz and Piliero, 1969). During the response to inflammation, the pro-inflammatory (e.g., TNF- $\alpha$ ) stimuli activates the cellular responses that increase production of many cytokines, including prostaglandins (PGs) and NO. The cyclooxygenase 2 (COX-2) is responsible for the increase in the levels of PGs in inflammatory conditions (Sims and Smith, 2010; Vodovotz et al., 2004). Numerous studies have indicated that $\mathrm{NO}$ and $\mathrm{PGs}$ participate in inflammatory and nociceptive events (Holthusen and Arndt, 1994). Inhibition of $\mathrm{NO}$ and PGs production via the inhibition of iNOS and COX-2 expression is beneficial in treating inflammatory diseases (Bogdan, 2001). Currently, steroids, nonsteroidal anti-inflammatory drugs (NSAIDS) and immunosuppressant drugs are used in the relief of inflammation and are often associated with severe adverse effects (Corley, 2003).
Matricaria recutita (Asteraceae) is also known as German chamomile and it is one of the most useful and well documented medicinal plants in the world (Salaman, 1992). The plant is rich in many active constituents such as several phenolic compounds primarily the flavonoids apigenin, quercetin, patuletin and luteolin. It also contains terpenoids, chamazulene and sequiterpenes. It is used externally for wounds, ulcers, eczema, gout, skin irritations, neuralgia, sciatica, hemorrhoids, leg ulcers, rheumatic pain (Newall, Anderson and Phillipson, 1996) and treatment of inflammation (Motavalizadehkakhky, 2012). It is traditionally used to treat anxiety, hysteria, nightmares, insomnia and sleep problems, convulsions and even delirium tremens (Martens, 1995). In the present study we evaluated the anti-inflammatory activity of Matricaria recutita against acute and chronic inflammatory models.

\section{MATERIALS AND METHODS}

\section{Plant Material}

In the present study, capitula of Matricaria recutita were collected from Horticulture University, Bagalkot, Karnataka, India during the month of June 2012. 
Katti et alo,

Herbarium was prepared and the specimen was further identified and authenticated in Department of Botany, Basaveshwar Science College, Bagalkot, Karnataka and voucher specimen (B.sc./Bot./14/2012) was deposited in the herbarium of the same college. The dried samples were reduced to a fine powder of \#44 and stored in amber colored air tight glass bottles. The powdered capitula were subjected to successive extraction with methanol $\left(64-65.5^{\circ} \mathrm{C}\right)$. After solvent was distilled off from the residue of extraction and excess solvent was completely removed by using a rotatory flash evaporator to get concentrated, then completely dried by lipolyzation (Mini Lyotrap, LTE Scientific Ltd. Great Britain), and stored in air tight container under refrigeration. The dried extract $(81 \mathrm{~g}$, percentage yield - 12.05\%) was used for antiinflammatory activity.

\section{Phytochemical Screening}

Phytochemical screening of methanol extract was carried out by employing the standard procedure and tests (Trease and Evaans, 1989).

\section{Animals}

Female Sprague-Dawley rats (200-250g) and Swiss Albino mice $(20-25 \mathrm{~g})$ were obtained from animal house of H.S.K. College of Pharmacy and Research Centre, Bagalkot. The animals were housed under standard conditions (temperature $25 \pm 2{ }^{\circ} \mathrm{C}$, relative humidity 50 $55 \%)$ for $12 \mathrm{~h}$ dark and $12 \mathrm{~h}$ light cycle respectively. They were given standard laboratory feed (Pranava Agro Industries Ltd, Sangli, Maharashtra) and water ad libitum. The study was conducted after obtaining clearance from the Institutional Animal Ethical Committee as per the CPCSEA guidelines (F. No. HSKCOP/IAEC, Clear/201112/1-14).

\section{Acute Toxicity Study}

Acute toxicity studies were carried out as per the OCED guideline No. 425, a method was adopted. The anti-inflammatory activity was performed at three dose levels 100, 200 and $300 \mathrm{mg} / \mathrm{kg}$ of body weight (Chandrashekhar, 2010).

\section{Carrageenan-induced Hind Paw Edema in Rats}

The acute anti-inflammatory effect was evaluated by carrageenan-induced rat paw edema according to the method described by Prabhakar et al. (2006) and Prashith Kekuda et al. (2013). Edema was induced by injecting carrageenan ( $1 \% \mathrm{w} / \mathrm{v}, 0.1 \mathrm{ml} / \mathrm{paw})$ in the right hind paw of rats. The extract of Chamomile $(100,200$ and $300 \mathrm{mg} / \mathrm{kg})$, Diclofenac $(10 \mathrm{mg} / \mathrm{kg})$, or vehicle was administered orally $1 \mathrm{~h}$ before the carrageenan administration. Paw volume was measured with digital Plethysmograph (Model No. 7140, Ugo Basile Srl, Comerio, Italy) after $0.5,1^{\text {st }}, 2^{\text {nd }}, 3^{\text {rd }}$ and $5^{\text {th }} \mathrm{h}$ injection. The \% increase in paw volume was calculated by the formula,

Percentage of inhibition of paw edema $=[\mathrm{Va}-\mathrm{Vb} / \mathrm{Va}] \times 100$

Where; Va: paw volume (ml) of control; Vb: paw volume $(\mathrm{ml})$ of test.

\section{Arachidonic Acid Induced Rat Paw Oedema}

The rats were divided into five groups of 6 animals each. Group I was treated as control and was given $1 \%$ normal saline. Group II received the standard dual blocker (Cyproheptadine and Nimesulide). Other 3 groups were pretreated with Chamomile extract (100, 200 and $300 \mathrm{mg} / \mathrm{kg}$ p.o.). Paw oedema was induced by single injection of $0.1 \mathrm{ml}$ of $0.5 \%$ Arachidonic acid in $0.2 \mathrm{M}$
Sci. Technol. Arts Res. J., Jan-March 2014, 3(1): 01-07

carbonate buffer ( $\mathrm{pH}$ 8.4) into the right hind paw (subplantar) of rats $1 \mathrm{hr}$ after drug treatment. Paw volume was measured as described above.

\section{Acetic Acid Induced Peritoneal Inflammation in Mice}

Mice (20-25gm) were weighed and divided into 6 groups with 6 animals in each group. Acetic acid (3\%; $0.1 \mathrm{ml} / 10 \mathrm{gm}$ of mice) in normal saline was administered to each animal (i.p.) $1 \mathrm{~h}$ after the administration of the methanol extract of Matricaria recutita L. (100, 200 and $300 \mathrm{mg} / \mathrm{kg}$ ) or Diclofenac $10 \mathrm{mg} / \mathrm{kg}$, which was used as a standard drug and writhing response was observed by the method of Turner (1965). Three hours later, the animals were sacrificed under anaesthesia, and the protein content in the peritoneal exudates was determined. The time of writhing and the number of writhing in 15 mins were noted (Koster, Anderson and De Beer, 1959).

\section{Chronic Inflammatory Model \\ Complete Freud's Adjuvant FCA-induced Arthritis in Rats}

Female Sprague Dawley rats (200-260 gm) were divided into five groups consists of FCA Control, Diclofenac (10 mg/kg, p.o.), Matricaria recutita L. (100, 200 and $300 \mathrm{mg} / \mathrm{kg}$, p.o.) with 6 animals each. On day 1, the induction of arthritis is done by injecting $0.1 \mathrm{ml}$ of FCA (each $\mathrm{ml}$ contains $1 \mathrm{mg}$ of Mycobacterium tuberculosis, heat killed and dried, $0.85 \mathrm{ml}$ of paraffin oil and $0.15 \mathrm{ml}$ of Manmide monooleate, Sigma Aldrich, Saint Louis, USA) into the sub-plantar region of right hind paw of rat (Kalia, Rao and Kutty, 2007). The rats are carefully observed for 28 days.

\section{Effect of Matricaria recutita on Paw Volume of FCA Induced Arthritis in Rats}

Paw volumes were measured on 0 day before injection and on the $7^{\text {th }}, 14^{\text {th }}, 21^{\text {st }}$ and $28^{\text {th }}$ day after the injection with digital Plethysmograph (Model No. 7140, Ugo Basile Srl, Comerio, Italy). The percentage inhibition of paw oedema volume of each treated groups is calculated as above.

\section{Effect of Chamomile Methanol Extract on Open Field} Test

Animals were subjected to open field test on $0,7^{\text {th }}$, $14^{\text {th }}, 21^{\text {st }}$ and $28^{\text {th }}$ day . Rat was placed in an open field in the sound-attenuated room. The flooring was white polyvinyl with a black grid dividing open field into 100 squares $(10 \times 10)$. Illumination was provided by a bulb $(60$ W) while the rest of the room was darkened and observations were made between $6 \mathrm{pm}$ and $10 \mathrm{pm}$. Observation were done for 5 minutes for all behavioural parameters, which include latency (in sec), time to start exploring the open field, ambulatory movements (horizontal locomotor activity or grid line crossed) (Costa, Sutter and Gybel, 1981), rearing (vertical locomotor activity), grooming (rubbing of nose with its forepaws and preening) and defecation (number of boluses) (Tomita, Yoshimi and Philip, 2006).

Effect of Methanol Extract of Matricaria recutita on Development of Arthritis in Rats

Development of arthritis was assessed after every seventh day up to 28 days, i.e. on $0,7^{\text {th }}, 14^{\text {th }}, 21^{\text {st }}$ and $28^{\text {th }}$ day after the injection of FCA for all groups. The scoring was done by using a three point scale for each paw; $0=$ normal joint, 1 =slight inflammation and redness; 2 = severe erythema and swelling affecting the entire paw with inhibition of use; and 3 = deformed paw or joint with 
Katti et alo,

ankylosis, joint rigidity, and loss of function (Franchis, Hilda and Ethel, 2004).

\section{Effect of Methanol Extract of Matricaria recutita on} Vascular Permeability

The rats are anaesthetized with ketamine hydrochloride (i.p.) $45 \mathrm{mg} / \mathrm{kg}$ body weight. Evan's blue (50 $\mathrm{mg} / \mathrm{kg}$ of B.W.) was administered via the jugular vein into the anaesthetized rat. After $4 \mathrm{hr}$, the rats were sacrificed and their anterior and posterior synovial capsules and fat pad were dissected from each knee joint and paw. The amount of evans blue in the sample was estimated by extracting the dye. The knee joints capsule and paw joints are cut into smaller pieces and mixed with acetone in $1 \%$ $\mathrm{NaSO} 4$ in the ratio of 7:3. The test samples were shaken continuously for $24 \mathrm{~h}$ at room temperature. Then each sample preparation was centrifuged for $10 \mathrm{~min}$ at 2000 $\mathrm{rpm}$ and $2 \mathrm{ml}$ of the supernatant was separated for measurement of absorbance at $620 \mathrm{~nm}$ using UVspectrophotometer (UV- 1601, Shimadzu Corporation, Kyoto, Japan. .The amount of dye retained in joint, by vascular permeability was calculated by using standard curve of different concentration of Evans blue. The percentage of vascular permeability or joint infiltration was calculated.

Percentage inhibition \% $=[1-\mathrm{Vt} /(\mathrm{Vc})] \times 100$

where, $\mathrm{Vt}=$ mean evans blue joint infiltration of treated groups; $V_{c}=$ mean evans blue joint infiltration of control group (Shore, Burkhalter and Cohn, 1959).

\section{Effect of Methanol Extract of Matricaria recutita on Release of Histamine from Blood}

The Diclofenac at the dose of $10 \mathrm{mg} / \mathrm{kg}$ and methanol extract of Matricaria recutita L. at doses of 100, 200 and $300 \mathrm{mg} / \mathrm{kg}$ of B.W. were given to rats daily for 28 days prior to collection of blood. On $28^{\text {th }}$ day the rats were sacrificed and then blood was collected by cardiac puncture and these blood samples are mixed with $6 \mathrm{mg}$ of ammonium oxalate and residual histamine in cells was released by disrupting the cells with perchloric acid and centrifugation at $400 \times \mathrm{g}$ for $5 \mathrm{~min}$ at $4^{\circ} \mathrm{C}$. the histamine content was determined by o-phthalaldehyde spectrofluorimetric method (Cai et al., 2006).

\section{Radiological Analysis}

Animals, on $28^{\text {th }}$ day were anaesthetized and radiographs of the adjuvant-injected hind paws were taken using x-ray (Model no DX-300., Pune, India). The film focus distance was $75 \mathrm{~cm}$ and the machine was
Sci. Technol. Arts Res. J., Jan-March 2014, 3(1): 01-07

operated at $46 \mathrm{kV}$ peak, $4 \mathrm{~mA}$ and exposure time was 0.8 sec. The radiological alterations were recorded for severity (Crunkhon and Meacock, 1971).

\section{Assessment of Morphological Changes}

The rats were anaesthetized and exsanguinated and their knee joints are dissected, freed from muscles and fixed in $10 \%$ formalin. The joints are decalcified, embedded in wax, sectioned and stained with haematoxylin and eosin. Histological analysis was carried out by a single observer, focusing on polymorpho-nuclear cell infiltration, tissue proliferation and cartilage erosions. The severity of the lesions was given scores: $0=$ no change, 1 = mild change, 2 = moderate change and $4=$ marked change (Shore, Burkhalter and Cohn, 1959).

\section{Statistical Analysis}

All the data are presented as mean \pm S.E.M. The significance of difference in means between control and treated animals for different parameters was determined by using one way analysis of variance (ANOVA) followed by multiple comparisons Dunnett's test. A value of $P<0.05$ was considered statistically significant.

\section{RESULTS}

\section{Phytochemical Screening}

Preliminary phytochemical screening showed the presence of flavonoids, saponins, tannins and volatile oils in methanol extract.

\section{Carrageenan-induced Hind Paw Edema in Rats}

The extract and Diclofenac inhibited carrageenaninduced paw edema by $44.78 \%, 67.35 \%$ and $54.70 \%$ at the dose of 100,200 and $300 \mathrm{mg} / \mathrm{kg}$ and $56.23 \%$ respectively, in the late phase at $5^{\text {th }} \mathrm{hr}$ after induction. Chamomile extract exhibited significant anti-inflammatory activity (Table 1).

\section{Arachidonic Acid Induced Rat Paw Edema}

Matricaria recutita (100, 200 and $300 \mathrm{mg} / \mathrm{kg}$ ) and dual blocker (Nimesulide and Cyproheptadine) were found to inhibit arachidonic acid induced paw edema significantly) $(P<0.05-<0.001)$ as compared to control (Table 1$)$.

\section{Acetic Acid Induced Peritoneal Inflammation in Mice}

In acetic acid induced writhing in mice, the methanol extract $(100,200$ and $300 \mathrm{mg} / \mathrm{kg}$ ) and Diclofenac decreased protein content as compared to control treated group (Table 2).

Table 1: Effect of Matricaria recutita on carrageenan induced paw edema and acetic acid induced peritoneal inflammation.

\begin{tabular}{|c|c|c|c|c|c|c|c|}
\hline \multirow{2}{*}{ Groups } & \multicolumn{5}{|c|}{ Carrageenan induced paw edema } & \multicolumn{2}{|c|}{$\begin{array}{l}\text { Acetic acid induced } \\
\text { inflammation }\end{array}$} \\
\hline & $1 / 2 h r$ & $1^{\text {st }} \mathrm{hr}$ & $2^{\text {nd }} \mathrm{hr}$ & $3^{\text {rd }} \mathrm{hr}$ & $5^{\text {th }} \mathrm{hr}$ & $\begin{array}{c}\text { No. of } \\
\text { writhing }\end{array}$ & $\begin{array}{c}\text { Total protein } \\
(\mathrm{mg} / \mathrm{ml})\end{array}$ \\
\hline Normal & --- & --- & --- & --- & --- & $0.00 \pm 0.00$ & $14.31 \pm 0.90$ \\
\hline Control & $0.361 \pm 0.03$ & $0.426 \pm 0.03$ & $0.488 \pm 0.04$ & $0.526 \pm 0.05$ & $0.585 \pm 0.06$ & $44.83 \pm 2.48$ & $34.89 \pm 2.01^{\mathrm{a}}$ \\
\hline $\begin{array}{c}\text { M.R. } \\
100 \mathrm{mg} / \mathrm{kg}\end{array}$ & $\begin{array}{l}0.155 \pm 0.05^{\star *} \\
(57.06 \%)\end{array}$ & $\begin{array}{l}0.251 \pm 0.02^{\star *} \\
(41.07 \%)\end{array}$ & $\begin{array}{l}0.333 \pm 0.03 \\
(37.76 \%)\end{array}$ & $\begin{array}{l}0.393 \pm 0.02 \\
(25.28 \%)\end{array}$ & $\begin{array}{l}0.323 \pm 0.02^{\star \star *} \\
(44.78 \%)\end{array}$ & $33.50 \pm 3.67^{\star}$ & $20.79 \pm 0.84^{\star \star \star}$ \\
\hline $\begin{array}{c}\text { M.R. } \\
200 \mathrm{mg} / \mathrm{kg}\end{array}$ & $\begin{array}{l}0.146 \pm 0.03^{\star \star} \\
(59.5 \%)\end{array}$ & $\begin{array}{l}0.230 \pm 0.02^{\star \star} \\
(46.0 \%)\end{array}$ & $\begin{array}{l}0.490 \pm 0.05 \\
(0.0 \%)\end{array}$ & $\begin{array}{l}0.381 \pm 0.05 \\
(27.56 \%)\end{array}$ & $\begin{array}{l}0.191 \pm 0.04^{\star \star *} \\
(67.35 \%)\end{array}$ & $32.83 \pm 2.94^{\star}$ & $17.54 \pm 1.14^{\star \star \star}$ \\
\hline $\begin{array}{c}\text { M.R } \\
300 \mathrm{mg} / \mathrm{kg}\end{array}$ & $\begin{array}{l}0.151 \pm 0.03^{\star *} \\
(58.17 \%)\end{array}$ & $\begin{array}{l}0.245 \pm 0.05^{\star *} \\
(42.48 \%)\end{array}$ & $\begin{array}{l}0.273 \pm 0.05^{*} \\
(44.05 \%)\end{array}$ & $\begin{array}{l}0.238 \pm 0.03^{\star \star *} \\
(54.75 \%)\end{array}$ & $\begin{array}{l}0.265 \pm 0.03^{\star * *} \\
(54.70 \%)\end{array}$ & $20.33 \pm 2.44^{\star \star \star}$ & $17.80 \pm 0.63^{\star * \star}$ \\
\hline
\end{tabular}

All the values are expressed as mean \pm SEM, $\mathrm{n}=6,{ }^{\star} P<0.05,{ }^{\star \star} P<0.01,{ }^{\star \star \star} P<0.001$ as compared to control group. One way Analysis of Variance (ANOVA) followed by multiple comparisons Dunnett's multiple comparison test. 
Table 2: Effect of Matricaria recutita methanol extract on arachidonic acid induced paw edema in rats.

\begin{tabular}{|c|c|c|c|c|}
\hline \multirow{2}{*}{ Groups } & \multicolumn{4}{|c|}{ Paw volume in $\mathrm{ml}$ (percentage of Edema inhibition) } \\
\hline & $1^{\text {st }} \mathrm{hr}$ & $2^{\text {nd }} h r$ & $3^{\mathrm{rd}} \mathrm{hr}$ & $5^{\text {lh }} \mathrm{hr}$ \\
\hline Control & $0.921 \pm 0.02$ & $1.093 \pm 0.06$ & $1.128 \pm 0.04$ & $0.928 \pm 0.03$ \\
\hline $\begin{array}{c}\text { Dual blocker } \\
\text { (Nimesulide and Cyproheptadine) }\end{array}$ & $\begin{array}{l}0.745 \pm 0.02^{* * *} \\
(19.11)\end{array}$ & $\begin{array}{l}0.583 \pm 0.04^{* * *} \\
(46.66)\end{array}$ & $\begin{array}{l}0.527 \pm 0.03^{* * *} \\
(52.83)\end{array}$ & $\begin{array}{l}0.512 \pm 0.03^{* * *} \\
(44.82)\end{array}$ \\
\hline M.R. $100 \mathrm{mg} / \mathrm{kg}$ & $\begin{array}{l}0.851 \pm 0.02 \\
(7.60)\end{array}$ & $\begin{array}{l}0.718 \pm 0.05^{\star \star *} \\
(37.49)\end{array}$ & $\begin{array}{l}0.796 \pm 0.05^{\star * *} \\
(29.43)\end{array}$ & $\begin{array}{l}0.666 \pm 0.06^{* *} \\
(28.23)\end{array}$ \\
\hline M.R. $200 \mathrm{mg} / \mathrm{kg}$ & $\begin{array}{l}0.775 \pm 0.04^{*} \\
(15.85 \%)\end{array}$ & $\begin{array}{l}0.683 \pm 0.03^{\star * \star} \\
(37.51)\end{array}$ & $\begin{array}{l}0.588 \pm 0.01^{* * *} \\
(47.87)\end{array}$ & $\begin{array}{l}0.533 \pm 0.01^{* \star *} \\
(42.56)\end{array}$ \\
\hline M.R. $300 \mathrm{mg} / \mathrm{kg}$ & $\begin{array}{l}0.732 \pm 0.01^{*} \\
(20.52)\end{array}$ & $\begin{array}{l}0.631 \pm 0.02^{* * *} \\
(42.26)\end{array}$ & $\begin{array}{l}0.530 \pm 0.03^{* * *} \\
(53.01)\end{array}$ & $\begin{array}{l}0.509 \pm 0.07^{* * *} \\
(45.15)\end{array}$ \\
\hline
\end{tabular}

All values are expressed as mean \pm SEM, $n=6$, One way Analysis of Variance (ANOVA) followed by multiple

Comparisons Dunnett's test, ns $=$ non-significant, ${ }^{\star} P<0.05,{ }^{* \star} P<0.01,{ }^{* \star \star} P<0.001$ ascompared to control group.

\section{FCA-induced Arthritis in Rats}

Chamomile methanol extract showed potential antiarthritic activity. Extracts $100,200,300 \mathrm{mg} / \mathrm{kg}$ and Diclofenac $(10 \mathrm{mg} / \mathrm{kg})$ showed significant inhibition $(P<0.001)$ of edema by $43.73 \%, 48.42 \%, 57.07 \%$ and $80.75 \%$ respectively on $28^{\text {th }}$ day as compared to control group (Table 3).

\section{Open Field Test}

In open field behavior model, FCA induced control group showed development of erythema, swelling, redness and pain in the right paw (FCA injected) of rats of control group and as a result of this, animals showed reduction in horizontal and vertical locomotor activity and increase in grooming behavior as compared to normal group. In contrast, the Diclofenac (10 mg/kg) and methanol extract of chamomile showed increased ambulatory movement $(P<0.05-P<0.001)$, rearing $(P<0.05-P<0.001)$ and reduced grooming $(P<0.05-$ $P<0.001)$ behavior on $28^{\text {th }}$ day of treatment as compared to control group (Data is not shown in Table).

\section{Development of Arthritis}

In development of arthritis (DOA) scoring, the control group showed redness, deformities, swelling and erythema at the paw joints of animals. But, Diclofenac (10 $\mathrm{mg} / \mathrm{kg}$ ) and extract of chamomile 100,200 and $300 \mathrm{mg} / \mathrm{kg}$ treated animals showed significant $(P<0.001)$ reduction of inflammation $76.49 \%, 83.33 \%, 83.33 \%$ and $64.70 \%$ respectively as compared to control group (Table 3).

Table 3: Effect of Methanol extract of Matricaria recutita on FCA induced paw edema.

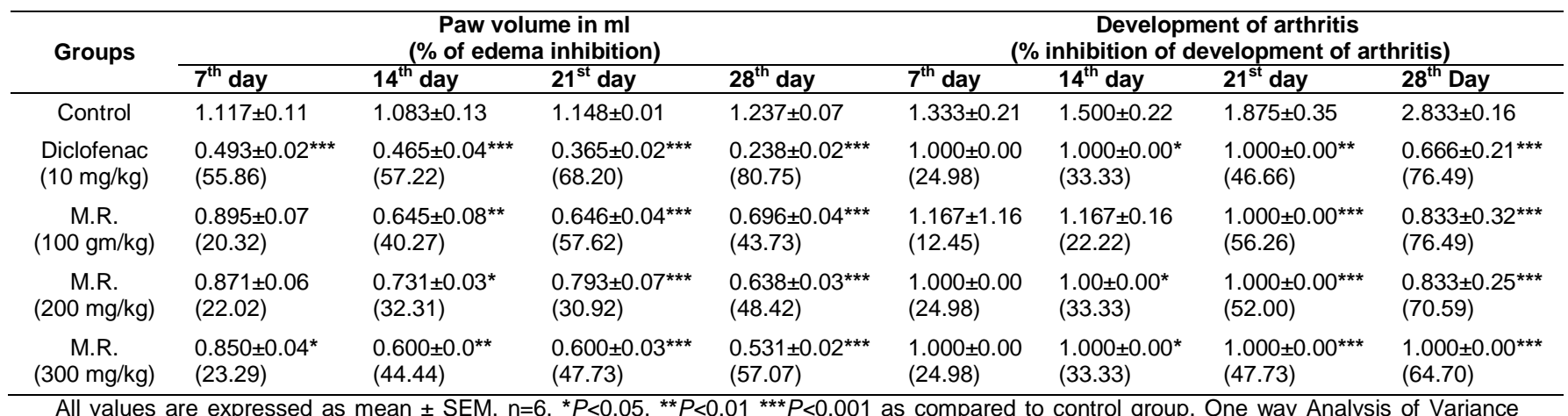

All values are expressed as mean \pm SEM, $\mathrm{n}=6,{ }^{\star} P<0.05,{ }^{\star \star} P<0.01{ }^{\star \star \star} P<0.001$ as compared to control group. One way Analysis of Variance (ANOVA) followed by Dunnett's multiple comparison test.

\section{Effect on Vascular Permeability}

In vascular permeability test, the Diclofenac (10 $\mathrm{mg} / \mathrm{kg}$ ), chamomile extract 100, 200 and $300 \mathrm{mg} / \mathrm{kg}$ treated groups showed significant $(P<0.001)$ inhibition of joint infiltration of Evans blue dye in the rat paw joints as compared to the control group (Table 4).

\section{Effect on Histamine Release in Blood}

In the histamine release in blood assay, the control group animals showed elevated histamine content in blood. In contrast, Diclofenac $(10 \mathrm{mg} / \mathrm{kg})$ and chamomile extract $(100,200$ and $300 \mathrm{mg} / \mathrm{kg}$ ) showed significant $(P<0.05$ to $P<0.001)$ reduction of release of histamine into the blood (Table 4).

\section{Effect on ESR}

In control group animals exhibited severe inflammation, by generation of acute phase reactants such as fibrinogens and immunoglobulins, which are increased in inflammation and leads RBC's to fall more rapidly and hence increased ESR's were observed. In contrast, Diclofenac $(10 \mathrm{mg} / \mathrm{kg})$ and methanol extract of Chamomile showed significant $(P<0.001)$ decreased ESR's as compared to control group (Table 4).

\section{Radiographic and Histopathological Changes}

Significant changes have been observed after taking the radiographs. The smooth muscle swelling was decreased in the Diclofenac $(10 \mathrm{mg} / \mathrm{kg})$ and Matricaria recutita extract $(100,200$ and $300 \mathrm{mg} / \mathrm{kg})$ treated groups. Joint spaces as well as deformities were decreased in treated groups as compared to control. In case of histopathological assessment, the degree of presence of inflammatory cells, lymphocytes, plasma cells and polymorphonuclear cells have reduced in Matricaria recutita $\mathrm{L}$. extract treated groups and the degree of cartilage erosion also reduced as compared to the control group (Figure 1). 
Katti et al.,
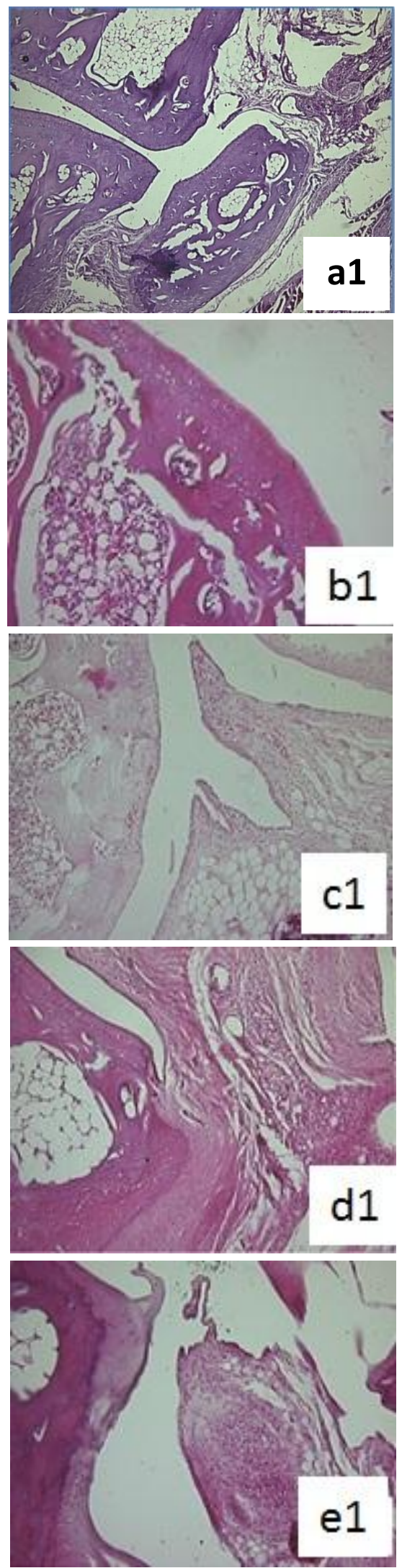

Figure 1: The extent of rat paw pathological conditions was graded on a semi quantitative scale. Light microscopy 10x. Paw joint tissue was fixed in $10 \%$ formaldehyde and $5-\mu \mathrm{m}$ paraffin sections were stained with hematoxylin and eosin. (a1 and a2) Grade 3: Destruction of cartilage and subchondral bone, disorganization of the joint space and replacement with mononuclear cells and fiber thickening, increased lymphocytes and plasma cells (control group); (b1, b2, e1 and e2) Grade 1: mild Proliferation and infiltration of mononuclear cells, mild subchondral bone erosion and superficial cartilage damage, Diclofenac $(10 \mathrm{mg} / \mathrm{kg})$ and M.R. (300 mg/kg); (c1, c2, d1 and d2) Grade 2: moderate pannus formation with superficial cartilage erosion M.R. (100 and $200 \mathrm{mg} / \mathrm{kg}$ ).

Sci. Technol. Arts Res. J., Jan-March 2014, 3(1): 01-07
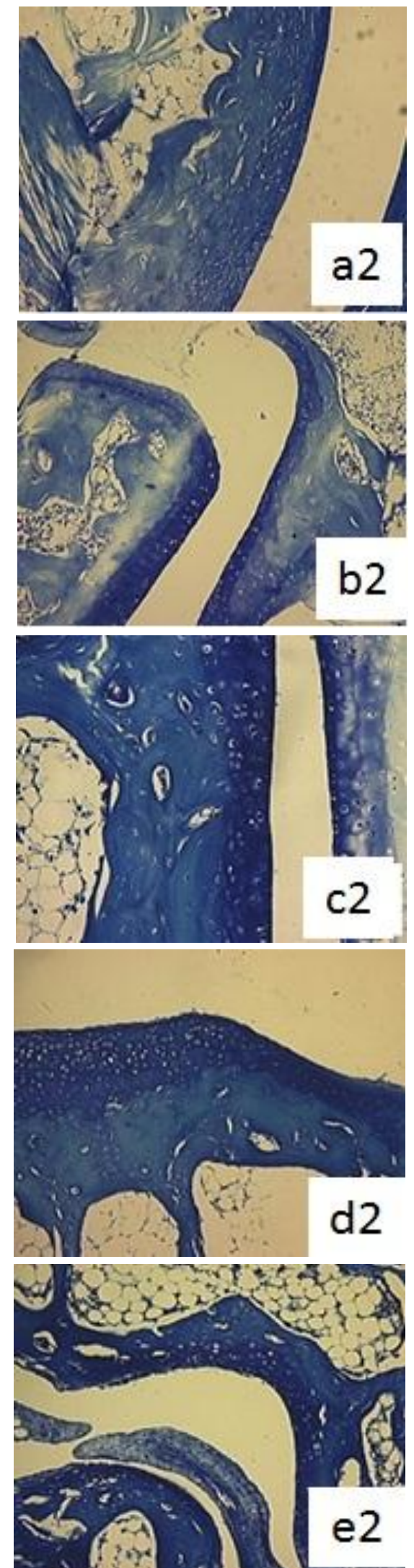
Table 4: Effect of Matricaria recutita on FCA induced Evans blue joint infiltration, histamine release and ESR.

\begin{tabular}{|c|c|c|c|c|c|}
\hline $\begin{array}{c}\text { Treatment } \\
\text { Groups }\end{array}$ & $\begin{array}{c}\text { Concentration } \\
\text { of Evans blue } \\
(\mathrm{mg} / \mathrm{ml})\end{array}$ & $\begin{array}{l}\text { Percentage of } \\
\text { inhibition of } \\
\text { joint infiltration }\end{array}$ & $\begin{array}{l}\text { Concentration of } \\
\text { histamine } \\
(\mu \mathrm{g} / \mathrm{ml})\end{array}$ & $\begin{array}{c}\text { Percentage of } \\
\text { inhibition of } \\
\text { histamine release }\end{array}$ & ESR \\
\hline Control & $5.33 \pm 0.70$ & $\overline{---}$ & $0.184 \pm 0.016$ & $\overline{---}$ & $10.00 \pm 0.447$ \\
\hline Diclofenac (10mg/kg) & $2.18 \pm 0.12^{\star \star \star}$ & 59.06 & $0.041 \pm 0.006^{\star \star \star}$ & 77.47 & $4.33 \pm 0.421^{* * *}$ \\
\hline M.R. $100 \mathrm{mg} / \mathrm{kg}$ & $1.91 \pm 0.10^{\star \star \star}$ & 64.12 & $0.108 \pm 0.003^{\star \star \star}$ & 41.20 & $2.66 \pm 0.333^{\star * *}$ \\
\hline M.R. $200 \mathrm{mg} / \mathrm{kg}$ & $2.42 \pm 0.2^{\star \star \star}$ & 54.49 & $0.105 \pm 0.003^{\star * \star}$ & 42.99 & $3.00 \pm 0.258^{* * *}$ \\
\hline M.R. $300 \mathrm{mg} / \mathrm{kg}$ & $1.89 \pm 0.22^{\star \star \star}$ & 64.50 & $0.061 \pm 0.003^{\star * \star}$ & 66.55 & $1.833 \pm 0.307^{\star \star *}$ \\
\hline
\end{tabular}

All values are expressed as mean \pm SEM, $n=6,{ }^{\star \star \star} P<0.001$, as compared to control group One way Analysis of Variance (ANOVA) followed by Dunnett's Multiple Comparison Test.

\section{DISCUSSION}

In the present study, the methanol extract of Matricaria recutita showed significant anti-inflammatory activity against acute carrageenan, archidonic induced rat paw edema and writhing acetic acid induced peritoneal inflammation and FCA induced chronic inflammation rats. The extract significantly reduced paw edema in carrageenan induced inflammatory model. The reduction of paw edema occurs at $3^{\text {rd }}$ and $5^{\text {th }} \mathrm{hr}$ of the induction, this indicates early and late phase of pro-inflammation agents inhibition (Crunkhon and Meacock, 1971). The methanol extract of Matricaria recutita showed significant reduced writhing response and total protein content against acetic acid induced peritoneal inflammation in mice. An inflammatory activity also includes the increase in the vascular permeability, which causes increased exudation of plasma proteins with migration of leucocytes but, in our experiment we observed a significant inhibition in the peritoneal exudation of plasma proteins after treatment with chamomile extract.

The FCA induced arthritis in rats has been very common and widely used method for a chronic model of inflammation. In this model, we observe chronic and immediate pain behaviours such as reduced locomotion, more scratching and itching. Paw swelling is the major factor to assess the degree of inflammation and to investigate the efficacy of the test drugs. The increased release of inflammatory mediators such as histamine in the blood also shows the inflammatory condition. In contrast to inflammation, in our study the methanol extract of Matricaria recutita was found showing significant antiinflammatory activity. Increase in locomotion and reduction in grooming and paw volume on $28^{\text {th }}$ day of injection of FCA was observed as compared to control. The release of histamine content in blood also reduced significantly.

FCA induced arthritis is thought to occur by cell mediated auto immunity by effect of mycobacterium on cartilage proteoglycans in rats (Van Eden et al., 1985). MR also reduced the arthritic scores along with paw swelling which shows immunosuppressive effects. WBC increases in arthritic conditions (Maria et al., 1983) and WBC were reduced by MR extract. Depletion in $\mathrm{Hb}$ content in arthritis results from reduced response of the bone marrow erythropoietin and also due to premature destruction of red blood cells. Erythrocyte sedimentation rate (ESR) is influenced by an increase in the plasma concentration in response to inflammation (Van Eden et al., 1985) and so, the platelet count gets elevated too. Matricaria recutita treatment showed significant reduction in ESR and platelets but did not show elevated effect on $\mathrm{Hb}$ and $\mathrm{RBC}$. Radiographic observations showed that by treating with Matricaria recutita, there is inhibition of joint related alterations in rat paws. Chamomile treated animals were showed that reduced the inflammatory cells such as lymphocytes, plasma cells and polymorphonuclear cells and cartilage erosion as compared to control group animals in histopathological studies.

\section{CONCLUSION}

The present study indicated that methanol extract of Matricaria recutita potentially possess the antiinflammatory and anti-arthritic activity. Matricaria recutita showed significant anti-inflammatory activity against acute carrageenan, archidonic induced rat paw edema and writhing acetic acid induced peritoneal inflammation and FCA induced chronic inflammation rats. The extract significantly reduced paw edema in carrageenan induced inflammatory model. Further research required to study the exact mechanism of action of Matricaria recutita at molecular level.

\section{ACKNOWLEDGEMENTS}

This work is supported under grant from Vision Group of Science and Technology, Department of Science and Technology, Bangalore, Karnataka (Grant No: VGST113/2011-12). The authors thank to Principal, H.S.K College of Pharmacy, Bagalkot, Karnataka, India, for providing necessary facilities during this research work.

\section{REFERENCES}

Bogdan, C. (2001). Nitric oxide and the immune response. Nature Immunology 2(10): 907-916.

Buch, M., Emery, P. (2002). The etiology and pathogenesis of rheumatoid arthritis. Hospital Pharmacy Journal 9: 510.

Cai, X., Wong, Y.F., Zhou, H., Xie, Y., Jiang, Z.H., Bian, Z.X., $\mathrm{Xu}$, H.X., Liu, L. (2006). The comparative study of Sprague-Dawley and Lewis rats in adjuvant induced arthritis. Naunyn-Schmiedeberg's Archives of Pharmacology 373(2): 140-47.

Chandrashekhar, V.M., Ranapariya, V.L., Ganapaty, S., Parashar, A., Muchandi, A.A. (2010). Neuroprotective activity of Matricaria recutita L against global model ischemia in rats. Journal of Ethanopharmacology 127(3): 645-51.

Corley, D.A., Kerhikowske, K., Verma, R., Baffler, D. (2003). Protective association of aspirin/NSAIDs and esophageal cancer. A systemic review and meta analysis. Gastroenterology 124(1):47-56.

Costa, M.D., Sutter, P.D., Gybel, J. (1981). Adjuvant induced arthritis in rats: A possible animal model of chronic pain. Pain 10(2):173-85. 
Katti et al.,

Crunkhon, P., Meacock, S.C.R. (1971). Mediators of inflammation induced in the rat paw by carrageenan. British Journal of Pharmacology 42(3):392-402.

Dimartino, M.J., Griswold, D.E., Berkowitz, B.A., Poste, G., Lewis, A.J. (1987). Pharmacologic characterization of the anti-inflammatory properties of a new dual inhibitor of lipooxygenase and cyclo-oxygenase. Agents Actions 20: 113-23.

Franchis, Y.L., Hilda, L.W., Ethel, S.K.N. (2004). Time course and substance $P$ effects on the vascular and morphological changes in adjuvant induced monoarthritis rats. International Immunopharmacology 4(2):299-310.

Holthusen, H., Arndt, J.O. (1994). Nitric oxide evokes pain in humans on intra-cutaneous injection. Neuroscience Letter 165(1-2):71-74.

Kalia, R., Rao, C.M., Kutty, N.G. (2007). Synthesis and evaluation of the anti-inflammatory activity of $\mathrm{N}[2-(3,5-\mathrm{di}-$ tert-butyl-4-hydroxyphenyl)-4-oxo-thiazolidin-3-yl]nicotinamide. Arznei-Forschung 57: 616-622.

Katz, L., Piliero, S.T. (1969). A study of adjuvant induced polyarthritis in the rat with special reference to associated immunological phenomena. Annals of the New York Academy of Sciences 147: 515-36.

Koster, R., Anderson, M., De Beer, E.J. (1959). Acetic acid for analgesic screening. Federation proceedings 18: 412.

Maria, M., Engeniusz, M., Miroslaw, K., Maria, K., Iwona, P. (1983). Adjuvant induced disease in rats, clinical findings and morphological and biochemical changes in the blood histological changes in internal organs. Rheumatology 2 231-245.

Martens, D. (1995). Chamomile: the herb and the remedy. The Journal of the Chiropractice Academy of Homeopathy 6:15-18.

Motavalizadehkakhky, A. (2012). Antimicrobial activity and chemical composition of essential oils of chamomile from Neyshabur. Iranian Journal of Medicinal Plantsh Research 6: 820-24.

Newall, C.A., Anderson, L.A., Phillipson, J.D. (1996). Herbal medicines: A Guide For Healthcare Professionals. Pharmaceutical Press, London.
Sci. Technol. Arts Res. J., Jan-March 2014, 3(1): 01-07

Prashith Kekuda, T.R., Onkarappa, R., Raghavendra, H.L. (2013). Pharmacological Activities of Streptomyces Species PO-178 Isolated from Rhizosphere Soil of Agumbe, Karnataka, India. Science, Technology and Arts Research Journal 2(2): 83-91.

Prabhakar, K.R., Veerapur, V.P., Bansal, P., Vipan, K.P., Reddy, K.M., Barik, A., Reddy, B.K., Reddanna, P., Priyadarsini, K.I., Unnikrishnan, M.K. (2006). Identification and evaluation of antioxidant, analgesic/anti-inflammatory activity of the most active ninhydrin-phenol adducts synthesized. Bioorganic and Medicinal Chemistry 14(21):7113-7120.

Salaman, I. (1992). Chamomile: a medicinal plant. The Herb, Spice and Medicinal Plant Digest 10: 1-4.

Shore, P.A., Burkhalter, A., Cohn, V.H. (1959). A method for the flourimetric assay of histamine in tissues. Journal of Pharmacology and Experimental Therapeutics 127: 182186.

Sims, J.E., Smith, D.E. (2010). The IL-1 family: regulators of immunity. Nature Reviews Immunology 10: 89-102.

Tomita, T., Yoshimi, K., Philip, S.T. (2006). THR-0921, a novel peroxisome proliferation-activated receptor gamma agonist, reduces the severity of collagen-induced arthritis. Arthritis Research and Therapy 8(1):R7.

Trease, G.E., Evaans, W.C. (1989). Pharmacognosy, $13^{\text {th }}$ ed. Bailliere Tindall, London. 683-684.

Turner, R.A. (1965). Analgesics. In: Turner RA, (ed.), Screening Methods in Pharmacology. London: Academic Press, p. 100.

Van Eden, W., Holoshitz, J., Nevo, Z., Frenkel, A., Klazman, A., Cohen, I.R. (1985). Arthritis induced by a Tlymphocyte clone that responds to mycobacterium tuberculosis and to cartilage proteoglycans. Proceedings of the National Academy of Sciences USA 82(15):51175120.

Vodovotz, Y., Kim, P.K., Bagci, E.Z., Ermentrout, G.B., Chow, C.C., Bahar, I., Billiar, T.R. (2004). Inflammatory Modulation of Hepatocyte Apoptosis by Nitric Oxide: In vivo, In vitro, and In Silico Studies. Current Molecular Medicine 4(7):753-62 